\title{
Propranolol for Infantile Hemangiomas
}

Moise L. Levy, MD, United States

Author Affiliation Moise L. Levy, MD, is physician in chief in Pediatric/Adolescent Dermatology at Dell Children's Medical Center of Central Texas, Austin, Texas.

Citation Global Adv Health Med. 2012;1(2):14-16

Key Words Hemangioma, propranolol, beta blocker, corticosteroids, segmental, PHACE, posterior fossa malformation, arterial, cardiac, eye anomalies, vascular birthmarks, timolol

\section{ABSTRACT}

Hemangiomas are common vascular birthmarks that usually present a predictable pattern of proliferation and ultimate involution. Most do not require any treatment. When intervention is clinically indicated, medical and surgical options exist. Historically, corticosteroids have been used and have been shown to slow or stop the growth of a majority of hemangiomas; however, growth concerns and infectious complications have complicated their use. In 2008, a letter to the editor in The New England Journal of Medicine described another serendipitous observation of the effect of the nonselective betablocker, propranolol, on hemangiomas in 9 cases. This finding has been expanded by the authors of this original observation as well as others.

\section{摘要}

血管瘤是常见的血管胎记，通常 以一种可预测的模式进行增殖和 最终退化。大多数血管瘤都无需 任何治疗。当干预治疗得到临床 证明时, 即可选择进行医药和手 术治疗。从历史观点上来说, 糖 皮质激素已被用于并已被证实能 够, 减缓或停止大多数血管瘤的 生长; 但随之出现的生长问题和 感染性并发症使该类药物的使用 变得更加复杂。在 2008 年, 刊登 在《新英格兰医学期刊》 (The New England Journal of Medicine) 上 的一封致编者信介绍了研究人员 在九个病例中就非选择性 $\beta$ 受体 阻滞剂普菜洛尔治疗血管瘤的疗 效所偶然观察到的另一项结果。 这一发现由上述最初观察结果及 其他结果的作者予以阐述。

\section{SINOPSIS}

Los hemangiomas son marcas de nacimiento comunes de origen vascular que acostumbran a seguir un patrón predecible de proliferación y, en última instancia, involución. La mayoría no requiere tratamiento y, en los casos en que se aconseja realizar una intervención por motivos clínicos, existen opciones médicas y quirúrgicas. Históricamente, se ha demostrado que el uso de corticosteroides reduce o detiene el crecimiento de la mayoría de los hemangiomas; sin embargo, las complicaciones infecciosas y las preocupaciones en torno al crecimiento han complicado su uso. En el año 2008, una carta dirigida al editor publicada en The New England Journal of Medicine describía otra observación fortuita advertida en nueve casos sobre el efecto del betabloqueante no selectivo propranolol en los hemangiomas. Se han efectuado trabajos de ampliación de este hallazgo por parte de los responsables de esta observación original, entre otros.
$\mathrm{B}$ irthmarks are common and are seen in approximately $8 \%$ of all newborns. ${ }^{\text {I }}$ Though they are usually of little significance from a clinical perspective, they often are of concern to families. Fortunately, a relatively small number of these are of medical significance. Clinicians describe hemangiomas according to their growth characteristics, location, and any associated complications, such as ulceration. ${ }^{2}$ Discrete hemangiomas are described as focal and are distinguished from a broader or widespread growth pattern called segmental. Segmental hemangiomas, when occurring over particular areas of the body, such as the face, often can be associated with internal structural brain, vascular, cardiac, and/or eye abnormalities. ${ }^{3}$ The association known as PHACE syndrome is now well characterized to describe the findings of posterior fossa malformation, (segmental) hemangioma, arterial, cardiac, and eye anomalies., ${ }^{4,5}$ With any hemangioma, management options include observation for the expected ultimate resolution, medical treatments, laser treatment, or surgical removal.
Treatment of wound-related complications is also important for some such cases.

This report will focus on medical therapies for hemangiomas. Historically, corticosteroids have been used after an early observation of their effect on the proliferative phase of such lesions. ${ }^{6}$ A majority of hemangiomas have been seen to slow in their growth phase or stop altogether with the use of corticosteroids. Due to often high-dose and long-term use, however, growth concerns and infectious complications associated with corticosteroids have complicated their use. ${ }^{7}$ In 2008, a report in The New England Journal of Medicine described another serendipitous observation of the effect of the nonselective beta-blocker, propranolol, on hemangiomas. ${ }^{8}$ Since that time, multiple reports have confirmed its often remarkable effects on the growth and evolution of these common birthmarks. ${ }^{9, \text { Io }}$ Concerns regarding potential side effects and the most appropriate means of administration continue to guide ongoing clinical experience with this very exciting new treatment modality. 


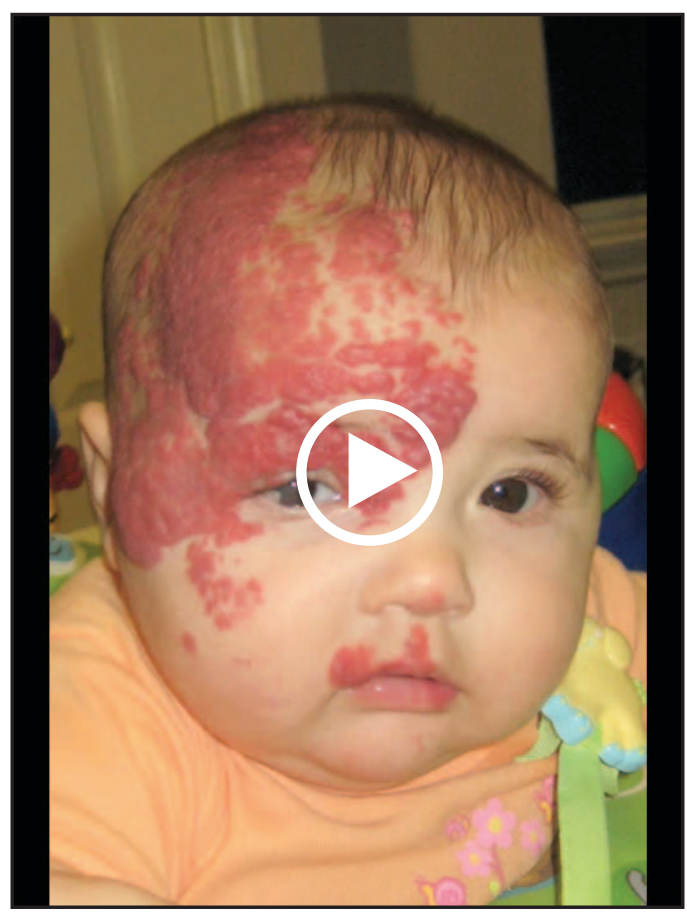

July 2008 - April 2009

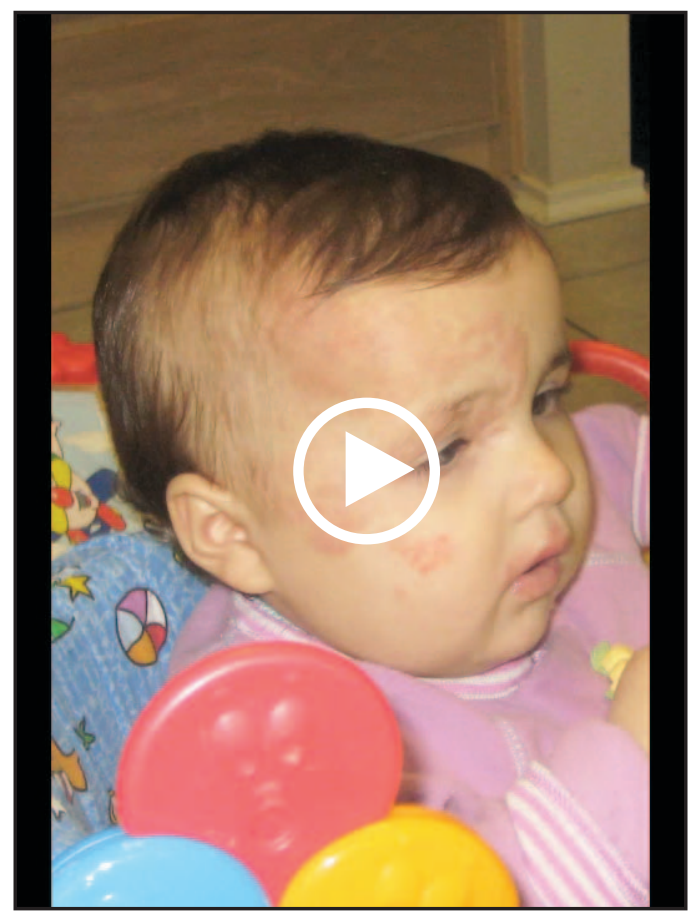

March 2009 - January 2012

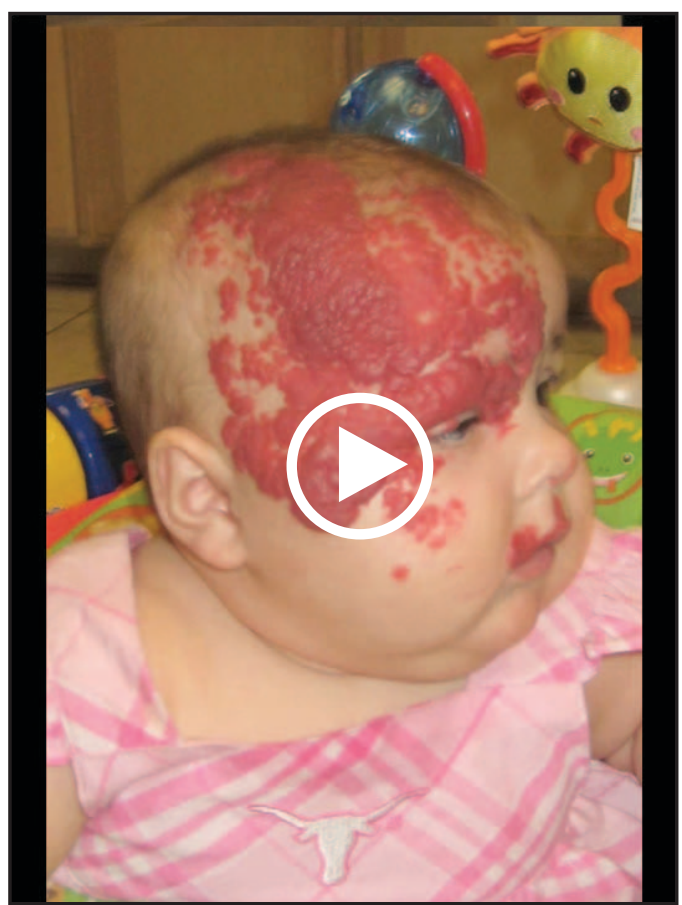

July 2008 - April 2009

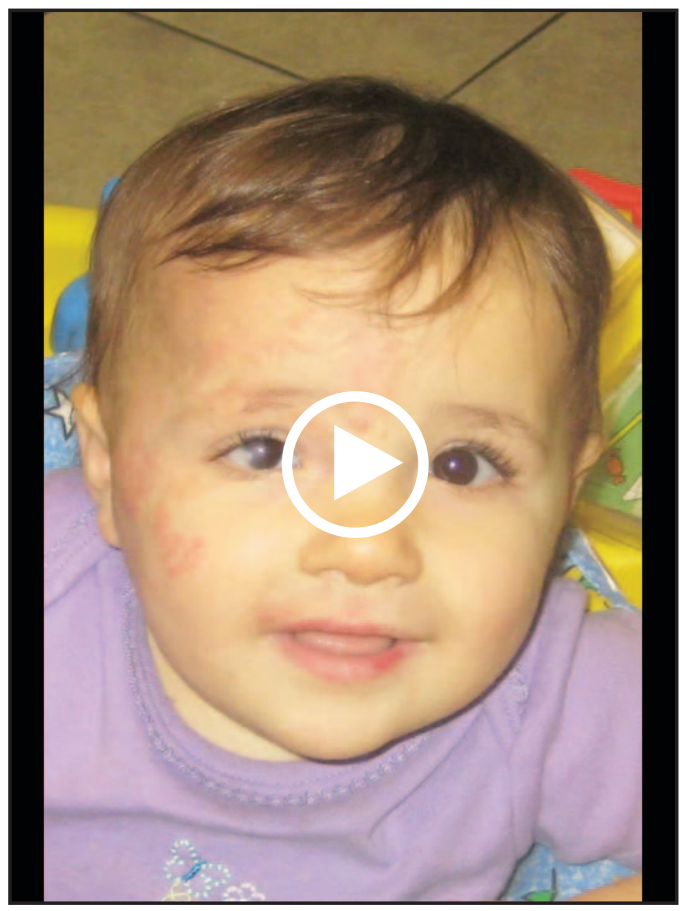

March 2009 - January 2012

Figure Videos showing patient prior to and during treatment with propranolol. Reprinted with permission from AngelPHACE.com.

\section{HISTORY}

A I-month-old girl was first seen for evaluation of a facial birthmark. Her history was significant for a fetal magnetic resonance imaging study at 24 weeks' gestation that showed absent corpus callosum after hydrocephalus was noted by ultrasound performed at 20 weeks. She was delivered by Cesarean section at 39 weeks.

An erythematous plaque was seen on the right face, upper and lower lips, and back of her head. She was felt to have a large segmental facial hemangioma, and due to the 
nature and location of the hemangioma, concern for PHACE syndrome was discussed with the family. Further imaging of the head and neck, as well as the heart, was ordered, and options for management of the hemangioma were discussed. An ophthalmologic examination was also conducted. Based upon imaging and eye-examination findings, PHACE syndrome was diagnosed. Laser and corticosteroids were reviewed and wound care for a small area of ulceration of the upper lip was discussed.

\section{TREATMENT}

Corticosteroids were begun at the time of the initial visit at a dose of $2 \mathrm{mg} / \mathrm{kg} / \mathrm{day}$. Enrollment in the PHACE syndrome registry was also suggested. Patients with a diagnosis of PHACE syndrome may have any or all of the conditions associated with it (eg, large segmental/patchy facial hemangiomas, eye, brain, head/neck vessel abnormalities, heart abnormalities). Diagnostic criteria are now well described. 5

The hemangioma stabilized over the next month. When the dose of the medication was decreased, the lesion's growth resumed, requiring an increase in the dose of the medication. After several months of therapy, the hemangioma again stabilized. After approximately 4 months of therapy, the report in The New England Journal of Medicine about propranolol use for infantile hemangiomas was discussed with the family. ${ }^{8}$ The patient was begun on a low dose of the medication with a slow advance of the dose concurrent with a decrease in the dose of the corticosteroid I month after publication of that report.

When the patient was seen in the office I week later, dramatic response of the hemangioma was noted. A cautious decrease of the corticosteroid was continued over the next several months, and the propranolol was continued with periodic adjustments of the dose consistent with her growth. Approximately Io months after starting the propranolol, a tapering schedule of the medication was begun (when the patient was I 5 months old). She was off of the medication approximately I month later.

When the patient was seen in the office 6 to 7 months later, some further ulceration of the hemangioma and discomfort were noted. Wound care and timolol solution were started. ${ }^{\mathrm{II}, \mathrm{I2}}$ The topical care was continued for several months with very good results (Figure).

During the management of the hemangioma, the patient was also seen by neurology, ophthalmology, and developmental specialists.

\section{DISCUSSION}

Several issues must be emphasized regarding this case. First of all, when clinicians evaluate patients with vascular birthmarks, arriving at the correct diagnosis is key to considering appropriate treatments. While most of such lesions can be easily classified, this is not always the case. ${ }^{13}$ Secondly, when infantile hemangiomas are diagnosed, physicians should be aware of the implications of segmental (vs focal) lesions. As noted above, criteria for consideration of PHACE syndrome must be kept in mind and the diagnosis pursued. Approximately $30 \%$ of patients with large facial segmental lesions are noted to have PHACE syndrome. ${ }^{14}$ In this setting, often significant head and/or neck arterial anomalies can occur, which might cause concern about the use of medications such as propranolol. While there is increasing experience with this agent for the management of large hemangiomas, a variety of methods of evaluation prior to its use exist. Similarly, some physicians begin treatment with propranolol on an outpatient basis and others (usually for selected patients) use it in the inpatient setting. At this time, the use of propranolol for this indication must be considered on an individual basis with respect to clinical need and available resources and expertise for follow-up.

Finally, this patient also received topical timolol, which is a topical beta blocker indicated for ophthalmologic use. Reports have cited its utility for some cases of hemangioma. ${ }^{\mathrm{II}, \mathrm{I2}}$ Again, matching its use to individual lesions has not been clearly defined. Issues relative to its potential absorption at certain skin sites and for particular lesions, such as ulcerated hemangiomas, also need to be clarified. In this instance, there have been no complications with its use, and some utility for ongoing management of this hemangioma has been noted by the child's parents and this physician.

\section{CONCLUSION}

This brief report reviews the successful use of propranolol for a complicated segmental hemangioma in the setting of PHACE syndrome. Careful monitoring of blood pressure and serum glucose appears to be appropriate for ongoing use of this medication. Pretreatment evaluation is of importance for all patients being considered for such treatment and should be individualized based upon each child.

\section{REFERENCES}

I. Alper JC, Holmes LB. The incidence and significance of birthmarks in a cohort of 4,64I newborns. Pediatr Dermatol. I983;I(I):58-68.

2. Chang LC, Haggstrom AN, Drolet BA, et al. Growth characteristics of infantile hemangiomas: implications for management. Pediatrics. 2008; I22(2):360-7.

3. Haggstrom AN, Lammer EJ, Schneider RA, Marcucio R, Frieden IJ. Patterns of infantile hemangiomas: new clues to hemangioma pathophysiology and embryonic facial development. Pediatrics. 2006: I I 7(3):698-703.

4. Metry DW, Haggstrom AN, Drolet BA. A prospective study of PHACE syndrome in infantile hemangiomas: demographic features, clinical findings, and complications. Am J Med Genet A. 2006; I4O(9):975-86.

5. Metry D, Heyer G, Hess C. Consensus statement on diagnostic criteria for PHACE syndrome. Pediatrics 2009; I 24(5): I447-56.

6. Fost NC, Esterly NB. Successful treatment of juvenile hemangiomas with prednisone. J Pediatr. I968;72(3):35I-7.

7. Frieden IJ, Eichenfield LF, Esterly NB, Geronemus R, Mallory SB. Guidelines for care of hemangiomas of infancy. American Academy of Dermatology Guidelines/Outcomes Committee. J Am Acad Dermatol. I997;37(4):63I-7.

8. Leaute-Labreze C, Dumas de la Roque E, Hubiche T, Boralevi F, Thambo JB, Taïeb A. Propranolol for severe hemangiomas of infancy. N Engl J Med. 2008;358(24):2649-5I.

9. Sans V, de la Roque ED, Berge J, et al. Propranolol for severe infantile hemangiomas: Follow-up report. Pediatrics. 2009; I24(3):e423-3I.

Io. Hogeling M, de la Roque ED, Berge J, et al. A randomized controlled trial of propranolol for infantile hemangiomas. Pediatrics. 20I I;I28(2):e259-66.

II. Guo S, Ni N. Topical treatment for infantile hemangioma of the eyelid using beta-blocker solution. Arch Ophthal. 2010;1 28(2):255-6.

I2. Pope E, Chakkittakandiyil A. Topical timolol gel for infantile hemangiomas: a pilot study. Arch Dermatol. 20I0;I46(5):564-5.

I3. Hassanein AH, Mulliken JB, Fishman SJ, Greene AK. Evaluation of terminology for vascular anomalies in current literature. Plast Reconstr Surg. 20I I;I 27(I):347-5I.

I4. Haggstrom AN, Garzon MC, Baselga E, et al. Risk for PHACE syndrome in infants with large facial hemangiomas. Pediatrics. 20I0;I26(2):e4I8-26. 